\title{
Local Communities' Energy Literacy as a Way to Rural Resilience-An Insight from Inner Peripheries
}

\author{
Justyna Chodkowska-Miszczuk $^{1} \mathbb{D}$, Maria Kola-Bezka ${ }^{2} \mathbb{D}$, Agata Lewandowska $^{3}$ and Stanislav Martinát $^{4, *} \mathbb{D}$ \\ 1 Department of Urban and Regional Development Studies, Faculty of Earth Sciences and Spatial Management, \\ Nicolaus Copernicus University in Torun, 87-100 Torun, Poland; jchodkow@umk.pl \\ 2 Department of Economic Policy and Regional Studies, Faculty of Economic Sciences and Management, \\ Nicolaus Copernicus University in Torun, 87-100 Torun, Poland; mkola@umk.pl \\ 3 Students' Scientific Association of Geographers, Faculty of Earth Sciences and Spatial Management, Nicolaus \\ Copernicus University in Torun, 87-100 Torun, Poland; 301713@stud.umk.pl \\ 4 Institute of Social and Economic Geography and Spatial Management, Faculty of Natural Sciences, University \\ of Silesia in Katowice, Będzińska Street 60, 41-200 Sosnowiec, Poland \\ * Correspondence: stanislav.martinat@ugn.cas.cz; Tel.: +420-585-634-501
}

Citation: Chodkowska-Miszczuk, J.; Kola-Bezka, M.; Lewandowska, A.; Martinát, S. Local Communities' Energy Literacy as a Way to Rural Resilience-An Insight from Inner Peripheries. Energies 2021, 14, 2575. https://doi.org/10.3390/en14092575

Academic Editor:

Dimitrios Katsaprakakis

Received: 23 March 2021

Accepted: 28 April 2021

Published: 30 April 2021

Publisher's Note: MDPI stays neutral with regard to jurisdictional claims in published maps and institutional affiliations.

Copyright: (c) 2021 by the authors. Licensee MDPI, Basel, Switzerland. This article is an open access article distributed under the terms and conditions of the Creative Commons Attribution (CC BY) license (https:// creativecommons.org/licenses/by/ $4.0 /)$.

\begin{abstract}
Energy transition is surely not only about the technological change, but it also has to necessarily reflect socio-cultural and environmental transformations on the local level. Hence, local communities' energy literacy belongs to the crucial elements in designing successful energy transition and strengthening rural resilience. Energy literacy is a concept widely related to the multifaceted phenomenon of energy consumption, both in its individual and collective dimensions. Therefore, the aim of the present study is to analyse the level of energy literacy in rural conditions, considering its three key dimensions (awareness, attitude, and behaviour). Our reflective considerations about energy literacy build on the current knowledge that stress its importance for the reinforcement of rural resilience. The case study, Zławieś Wielka, in the north-central Poland, was selected where a social survey $(\mathrm{N}=300)$ on the relation between energy literacy and rural resilience was conducted. By means of employing the cross-tabulations method for data analyses, our results signal that certain indications of the ecological awareness among the rural residents are being formed. Our findings clearly suggest that, on the one hand, the needs for more environmentally reasonable management with energy, including electricity and heat, come to the fore. On the other hand, various types of investments in improving the energy efficiency of residential buildings and utilising energy generation from renewable energy sources are observed. It seems that the surveyed community has a clear potential to become the vector for sustainable and just energy transition of the countryside. The essential conditions that urgently need to be implemented to ensure the viability of rural energy transition are the educational reinforcement within the community and more generous long-term institutional support from the central government, targeted on endogenous development and enhancing the local social capital.
\end{abstract}

Keywords: energy literacy; rural resilience; energy transition; local communities; Poland

\section{Introduction}

Currently, as a result of ongoing environmental crisis, we are experiencing constant changes covering all spheres of the socio-economic life. These changes are observed on every spatial scale (global, international, national, regional, and local), and concern all the economic sectors and activities of our institutions, as well as our behaviour as a society and as individuals. The uncertainty associated with the constant transformations that a society is undergoing, and the ever-present risks, are an immanent feature of these phenomena. Ulrich Beck [1] even speaks of a 'risk society'. Today, we are dealing with a 'manufactured risk' which is a consequence of extremely dynamic technological development and the general progress of our civilisation. This instability is also related to the multidimensional 
effects of strong anthropo-pressures on the environment, manifested in climate change or the depletion of conventional energy resources. In such uncertain and turbulent times, it is necessary to look for new tools for development and management, for helping the regions to recover from socio-economic and environmental crises, and for restoring more environmental-friendly stability $[2,3]$.

\subsection{Energy Literacy}

The key prerequisite here is to acquire a comprehensive knowledge, including a better understanding of the question, 'what is the role of energy in our everyday lives?'; and to use the acquired knowledge to solve contemporary problems and strengthen sustainability, at the same time. There is no doubt that the outlined advancements urgently need to be widely supported by following the guidelines of energy literacy [4]. Energy literacy is a concept related to the multifaceted phenomenon of energy consumption; therefore, it requires to be analysed both within the individual (household and domestic) and the collective (business, public institution sector, and societal level) contexts [5,6]. Moreover, energy literacy refers to the direct energy use of electricity, e.g., by consumers, or, indirect energy use embedded in the production, transportation, and disposal of goods and services [7].

Generally, households' (individual) energy literacy can be understood as the knowledge or awareness about the key energy issues relevant to everyday life (p. 12, [8]). Such an approach encompasses knowledge about the energy consumption of domestic appliances, knowledge about the actions allowing energy saving in the households, knowledge on how to constitute energy-efficient and environmentally friendly economic decisions, and about the relation between energy use and climate change. The basic energy-related knowledge necessary for energy transition, as demonstrated by many studies [9-11], does not determine the efficient use of energy in homes, the decisions leading to reduced energy expenditure in domestic budgets, and climate actions. Hence, energy literacy, rather in the more recent literature, emerges as a broad concept encompassing three key dimensions (knowledge, attitude, and behaviour). Awareness comes down to the understanding of the basic concepts, rules, theories, energy transfers, and transformation processes, as well as the role that energy plays in everyday life. Attitude means the convictions and ideologies of each person and one's personal relationship with the energy problems based on the energy knowledge, all of which are crucial in the decision-making process. Behaviour is manifested in the commitment to energy conservation efforts [12-14]. The cognitive domain of energy literacy, which is to be the foundation for the attitude domain and behaviour, should also include the basic financial knowledge that gives people the necessary skills to perform financial calculations concerning particular decisions about energy issues [4,9,15-17]. Such financial energy literacy, as a type of a broader concept of financial literacy [18], reflects on one's ability to judge the financial impact of energy consumption with a focus on the financial savings of an energy-saving investment [7].

Energy literacy, in this view, is a prerequisite for effective individual engagement in energy transition. However, it may not be a strong enough facilitator of such engagements, because the individuals' engagement in energy transition also depends on socio-psychological and socio-economic (contextual) variables [19]. However, undoubtedly, the knowledge on the basic issues concerning energy conservation at home, increasing household energy efficiency, and their use of renewable energy sources (awareness); convictions about the legitimacy of decarbonisation of the local economy and environmental protection (attitude); and individual actions taken to counteract climate change, i.e., application of knowledge in everyday situations (behaviour), all of these issues overwhelmingly determine the households' energy consumption. They are thus, on the one hand, factors of great significance for the effectiveness of energy transition processes. On the other hand, they can be extremely important in enhancing the resilience of local territories and local communities, particularly in rural areas, to the effects of decisions and actions taken on a global scale in response to the challenges of sustainable development and climate change. 


\subsection{Rural Resilience}

Generally speaking, resilience is the ability of a socio-ecological system to cope with and adapt to social, political, and environmental disruptions [20,21]. Building this resilience is particularly important in rural areas that face dynamic changes and uncertainty related to economic activity, including agriculture, but also to energy transition. The concept of resilience was introduced to rural development studies, relatively recently (in late 2000s) [22]; therefore, its scope with respect to rural areas has not yet solidified. Clearly, rural resilience is an offshoot of other types of resilience (such as economic, ecological, and cultural resilience). When considering rural areas in a systemic way, resilience can be defined as the ability to recover in a dynamic environment, being a kind of buffer that protects the (rural) system from mismanagement or adverse policy actions [22]. The opportunity here lies in taking action to strengthen human and social capital. Shaping local communities in the spirit of rural resilience allows for new and more sustainable trajectories of rural development $[2,23]$. Among the most important endeavours to stimulate the building of continuous adaptive capacity in local communities are education, creation of new knowledge, and flexibility in adopting new practices [3,21,24,25].

From the point of view of effective and sustainable rural development, it is important to employ a holistic approach to enhance resilience, i.e., by seriously considering its different types [26,27]. Given the need for the sustainable management of natural resources, on the one hand, and the growing energy demand, on the other, it is vital for the future of rural areas to enhance the resilience of the energy system [28]. This needs to be carried out in combination with the actions taken in a climate-resilient housing sector, which is now one of the essential prerequisites for a just energy transition aimed at reducing energy exclusion or poverty $[29,30]$. Rural power-system resilience is formed by three interdependent and interacting components, which are: economic, technical, and social resilience. Economic resilience should be understood here mainly through the prism of available financial resources, both in the investment and operation phase of new energy facilities and infrastructure. Technical resilience means increasing energy security through the diversification of energy sources, an increased share of renewable energy sources, and the spread of off-grid energy systems. It also manifests itself in the implementation of intelligent energy management characterised by flexibility and self-organisation, leading to the use of locally available resources in dealing with risks, e.g., using conservation techniques and increased energy efficiency. Social resilience, in turn, includes primarily community engagement and knowledge transfer [28]. It is extremely important to look for new solutions that are dedicated to rural areas and take into account their specificity and based on a long-term action, so as not to fall into the 'resilience trap' [31]. Essential to this is building public engagement and a sense of empowerment that will improve the transposition of energy policies constructed at the national and international levels down to the local scale [32]. As Olave and Vargas-Payera [33] rightly point out, "energy transition is not only about the technology change from fossil fuels to renewables. It also has to deal with the social, economic, and environmental aspects of the development of clean energies." Not only the newer generations, as argued by Lee et al. [14], but also, more generally, all the members of local communities will refrain from consuming energy responsibly if they are energy illiterate. The success of the transition and rural resilience may therefore depend on the local community's energy literacy (Figure 1). 


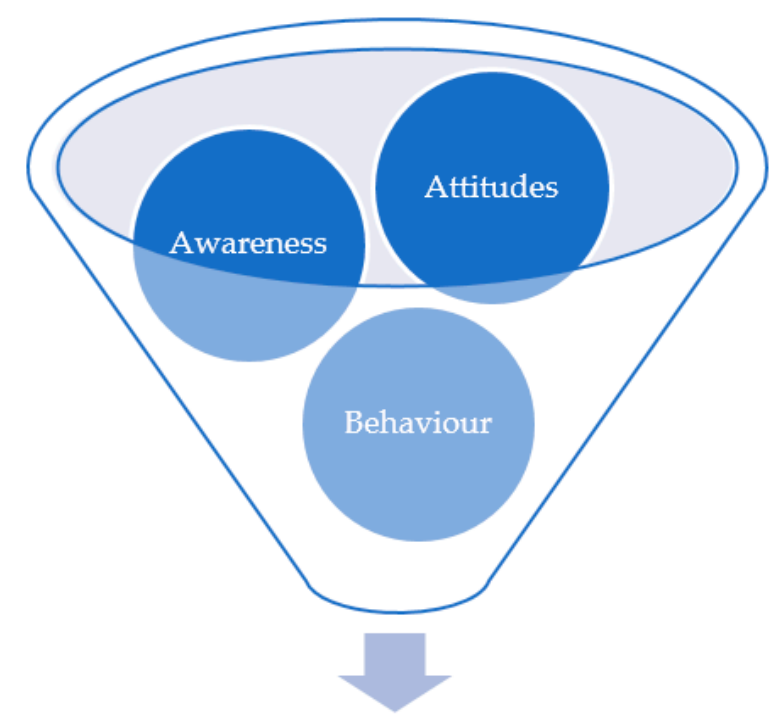

Rural resilience (social, economic, technical)

Figure 1. Community energy literacy and rural resilience. Source: own elaboration

\subsection{The Objective of the Study}

The overall objective of the study is to analyse energy literacy on the example of the local community, considering its three key dimensions (awareness, attitude, and behaviour) as an opportunity to enhance rural resilience. The research is operationalised by means of three partial aims that include: (1) to explore the energy literacy of a local community as household owners; (2) to determine the relationships between energy conservation behaviour and the use of renewable energy resources with awareness and attitude; and (3) to explore the effects of socio-economic factors on energy conservation behaviour and the use of renewable energy resources.

This paper focuses on the energy literacy of local communities only in the domestic context and in relation to the direct consumption of energy. The analysis was carried out with reference to Poland as a country undergoing energy transformation, with almost half a century of centrally planned economy and distinguished by the hegemony of entities related to coal mining. A detailed empirical study was conducted in the commune (LAU 2) of Zławieś Wielka, located in the Kujawsko-Pomorskie Voivodeship (NUTS 2). It is a region characterised by some of the highest values of energy poverty in Poland, as measured by the share of households whose ratio of energy expenditure to income is twice the median of this indicator [34].

\section{Research Design, Case Study Description, and Methodology}

\subsection{Research Design}

To shed more light on the issues related to rural resilience, the authors decided to combine social science research methods to enable a more in-depth understanding of local communities' energy literacy and to learn more about the specific features constituting the idea of rural resilience. After a detailed study of the latest research methods in the field, the authors decided to implement two research perspectives: macro scale (European and national levels) and micro scale (local level) perspectives (Figure 2). At the macro scale, a set of data (from the Local Data Bank of Statistics Poland, LDB SP) [35] and materials illustrating the energy attitudes and behaviour of the Polish society were analysed by means of desk research, which is a non-reactive research method [36]. On the other hand, at the micro-scale, empirical studies were conducted exploring the behaviour and energy practices of the local society, based on the example of the residents of the rural commune of Zławieś Wielka, in the Kujawsko-Pomorskie Voivodeship. 


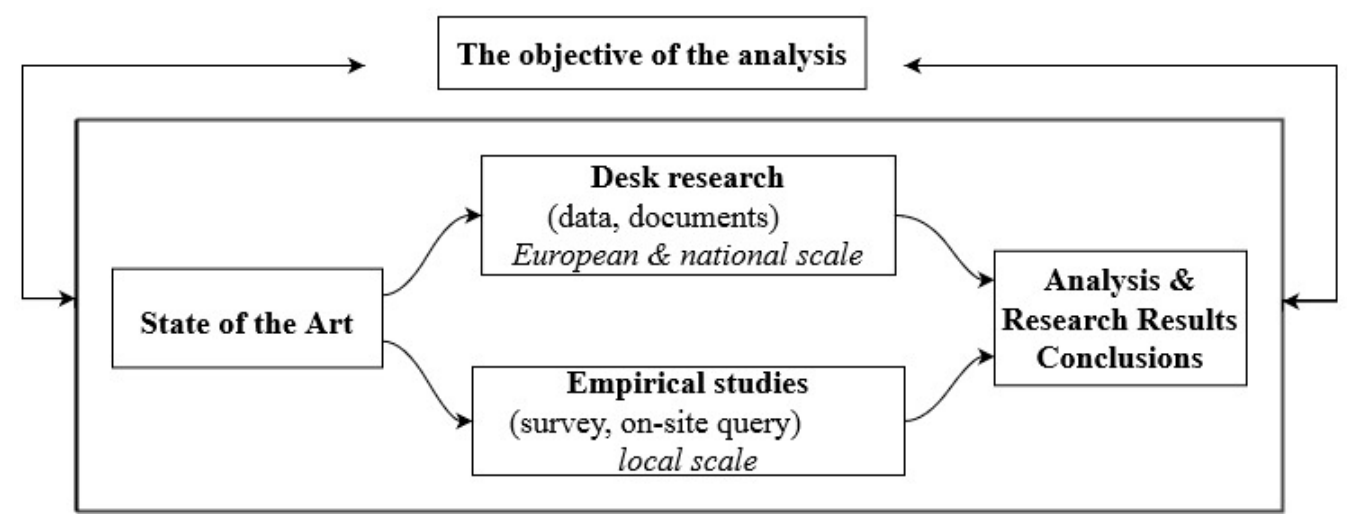

Figure 2. An outline of the research procedure. Source: own elaboration.

\subsection{Case Study Description}

Currently, one of the key energy transition issues is to ensure a socially just transition that takes into account the important role of a climate-resilient housing sector and a specific support for those at risk of energy exclusion and poverty [29]. Therefore, the commune of Zławies Wielka (population 14,386 in 2019; the area of $177.9 \mathrm{~km}^{2}$ ) was selected as the case study for a detailed empirical research. This is a rural area located in a region substantially struggling with energy poverty $[34,37]$. The problem is particularly visible and affects the population of rural communities living in single-family houses that are concentrated in peripheral areas. This type of region is suitably represented by the commune of Zławies Wielka. Despite its seemingly beneficial location between the two most important urban centres of the region (Bydgoszcz and Torun), the spatial layout of the commune, defined by a considerable elongated shape with difficult transport accessibility, is a typical feature of peripheral areas [38]. There is an obvious risk that the process of peripheralisation might be even strengthened here; due to its location in the centre of the region, the area would be referred to as internal periphery. The commune experiences the mild effects of the suburbanisation processes originating in regional urban cores; nevertheless, from the point of view of its function, this is primarily an agricultural commune. The commune has been mildly growing in population by the annual average of $1.5 \%$, in the last decade. The basic demographic and social structure of the commune is summarised in Table 1.

Table 1. The socio-demographic features of the case study-Zławieś Wielka commune (2019).

\begin{tabular}{ccccc}
\hline Population & Female & Male & Number of Employed & Population Density \\
\hline 14,386 & 7255 & 7131 & 1670 & 81 persons $/ \mathrm{km}^{2}$ \\
\hline
\end{tabular}

Source: own study based on data from LDB SP.

\subsection{Methodology}

We widely utilise empirical analyses to trace and capture the peculiarities of rural communities' emerging environmental consciousness under the shaky and uncertain conditions of socio-cultural and economic transformation. Based on previous research and experience of the authors [39,40], a set of questions for a PAPI-type of social survey (Paperand-Pen Personal Interview) [41] was developed and tested. A total of 300 questionnaires were obtained from the population of Zławieś Wielka (older than 18 years; please see the structure of our sample in Table 2). Our goal was to collect a balanced sample that reflects local demographic and social characteristics (altogether, we approached $2.7 \%$ of the adult population of the commune); the rate of returned questionnaires was $94 \%$. The survey was performed in the autumn of 2019. The survey form was formulated based on approximately a dozen closed-ended survey questions, using a hybrid mode. In addition to the nominal and dichotomous scales, multiple-choice answers were included so that the frequency of the selected energy practices could be assessed, and a hierarchy of behavioural 
motivations could be consequently established. The central idea of the questionnaire use for the social survey was the issue of ecological awareness as well as energy attitudes, behaviours, and decisions. The use of multiple-choice answers is highly appropriate in this case because respondents rate these types of questions more easily, as they do not require too much time and attention, which allows for a satisfactory survey result and an acceptable level of saturation [42,43]. The design of the response alternatives was based on the answers to open-ended questions obtained during the pre-test of the questionnaire, which was conducted in spring 2019 , by the local community. Thus, the relevance and comprehensibility of the individual questions and alternative answers were verified to include a set of all possible choices [44]. The results of the study were digitised and analysed in the IBM SPSS software. The analyses undertaken were performed using the cross tabulations method. This method enables examining the relationships within the data, portraying precise, impactful insights from data sets, and capturing differences and similarities in various social groups' energy behaviours and attitudes; the cross tabulations contributed to achieving the research objective.

Table 2. Socio-demographic structure of respondents.

\begin{tabular}{|c|c|c|c|c|c|c|c|c|}
\hline \multicolumn{2}{|c|}{ Gender } & \multicolumn{5}{|c|}{ Time of Residence in the Commune } & \multicolumn{2}{|c|}{ Type of Building Occupied } \\
\hline $\mathrm{F}$ & $\mathrm{M}$ & $\begin{array}{l}\text { less than } \\
\text { a year }\end{array}$ & $1-5$ years & $6-10$ years & $\begin{array}{l}\text { More than } \\
10 \text { years but } \\
\text { not since birth }\end{array}$ & Since birth & $\begin{array}{l}\text { Single-family } \\
\text { house }\end{array}$ & $\begin{array}{c}\text { Apartment in a } \\
\text { multi-family } \\
\text { house }\end{array}$ \\
\hline $59.7 \%$ & $40.3 \%$ & $1.7 \%$ & $9.7 \%$ & $14.0 \%$ & $31.3 \%$ & $43.3 \%$ & $84.1 \%$ & $15.9 \%$ \\
\hline
\end{tabular}

Source: own study, $\mathrm{N}=300$.

\section{Research Results}

3.1. An Outline of the Energy Situation of Households in Poland and Energy Attitudes and Behaviour of Polish Society

While, in most EU countries, natural gas is the dominant energy carrier used in households, in Poland, solid fuels, mainly hard coal and firewood, are prevalent in the structure of household energy consumption [34]. The share of hard coal in total domestic energy consumption in Poland, in 2018, was 32\% (EU-28 average 2.6\%), while, for firewood, it was $13.2 \%$ (EU-28 15\%). Both resources were most often used for heating the space (by $45.4 \%$ of the households) and water heating (25.6\% of the households), and much less for cooking meals (3.2\%). The share of households using hard coal and firewood is significantly higher in rural areas than in urban areas; in rural areas, in 2018, it was 71.3\% and $63 \%$, respectively, and in urban areas, it was $20 \%$ and $13.9 \%$, respectively. Firewood is generally burned in the same boilers and furnaces as hard coal, either simultaneously with coal or interchangeably. The scale of hard coal consumption by households makes Poland an infamous leader in the EU in this respect. To be more specific, the share of Polish households in hard coal consumption of all EU households in 2017 was $84 \%$, while their share in renewable energy consumption of all EU households was only $5 \%$ (Table 3).

Table 3. Energy consumption in households by energy carriers in Poland and in the EU, and the share of Poland in the EU-28 energy consumption, in 2017.

\begin{tabular}{ccccccccccccc}
\hline Country & \multicolumn{2}{c}{$\begin{array}{c}\text { Population } \\
\text { in }\end{array}$} & \multicolumn{2}{c}{ Total Energy } & \multicolumn{2}{c}{ Natural Gas } & \multicolumn{2}{c}{ Hard Coal } & \multicolumn{2}{c}{$\begin{array}{c}\text { Wood } \\
\text { Renewable } \\
\text { Energy }\end{array}$} \\
& Thousand & in \% & in TJ & in \% & in TJ & in \% & in TJ & in \% & in TJ & in \% & in TJ & in \% \\
\hline UE-28 & 511,373 & 100 & $12,056,936$ & 100 & $4,345,893$ & 100 & 317,419 & 100 & $1,809,026$ & 100 & $2,114,326$ & 100 \\
UE-15 & 407,194 & 80 & $9,835,796$ & 82 & $3,794,743$ & 87 & 31,043 & 10 & $1,272,782$ & 70 & $1,561,128$ & 74 \\
Poland & 37,973 & 7 & 834,683 & 7 & 151,972 & 3 & 267,709 & 84 & 109,725 & 6 & 114,164 & 5 \\
\hline
\end{tabular}


The scale of energy poverty in Poland is relatively high, although, as the statistics show, it has a downward trend. In the Kujawsko-Pomorskie Voivodeship, in which the examined commune is located, this indicator equals $19.4 \%$ and is one of the highest in Poland. Another objective indicator-Low Income High Costs, which takes into account both the technical condition of buildings and the material status of households, was $9.4 \%$ for Poland, in 2018 (11.1\% in 2012) and 9.7\% for the Kujawsko-Pomorskie Voivodeship [34]. Fuel poverty is higher in rural areas than in urban areas due to the generally lower incomes of rural populations and differences in the structure of the housing fabric [46].

An interesting picture of the energy awareness of the Polish society emerges from the results of a representative survey conducted by the Public Opinion Research Centre (Table 4). They indicate that environmental pollution, climate change, and depletion of non-renewable energy sources, next to lifestyle diseases, poverty, and the use of chemical compounds and genetic modifications in food products, are considered by Poles to be the most serious threats related to modern civilisation development. Most of the respondents (81\%) were aware of their personal impact on the state of the environment, and only $16 \%$ shared the view that one person's actions in this regard mean nothing. Two-thirds of Poles felt that their actions could contribute to improving the environment in their locality, while over a quarter held the opposite view. Most of the respondents reported using electricity sparingly at home. Almost all of them said that they turned off the light when leaving the room and used energy-saving bulbs or low-consumption appliances. In general, the question about the source (conventional or renewable) of electricity used in the home was important to nearly two-thirds of Poles. Declarations regarding the high importance of this issue were more frequent, the better assessment regarding their personal material living conditions. Among various energy sources, RES (renewable energy sources) were rated by far the highest, both in terms of safety (in relation to their threat to humans, the environment, and the climate) and prospectiveness, understood as an opportunity to ensure energy security for Poland in the future. Oil and coal, on the other hand, received the lowest ratings, especially in the forward-looking dimension. The social image of energy sources is reflected in the preferences of Poles regarding the desired directions of energy development. The most widely represented view (50\% of the respondents) was that policy should focus on developing RES-based energy. Twenty-two percent of the respondents considered installing renewable energy equipment in their home or outbuilding, in the next $2-3$ years, with $7 \%$ strongly considering it. They are mainly rural residents, and the preferred energy source is solar energy.

\subsection{Energy Literacy of the Local Community}

\subsubsection{Resilient Households?}

Considering households in the context of their importance in implementing rural resilience, a detailed analysis of heat generation sources was conducted. This decision was prompted by the fact that more than $84 \%$ of the respondents live in single-family homes (Table 5). These are residential buildings with individual heat and hot water sources, as opposed to grid-sourced electricity. Heat from the network supplies the apartments in multi-family buildings. According to the research, the raw material structure for heat production consists of three basic conventional sources: coal, eco-pea coal, and wood (Figure 3). Of these, coal is the most important. The second position is occupied by eco-pea, which is de facto coal, but of selected, high calorific value. Burning eco-pea coal results in the lower emission of pollutants into the atmosphere. The third place is taken by wood. All three of these raw materials are extremely popular for heating single-family buildings, where they account for more than $96 \%$ of all heat sources for wood and more than $93 \%$ for coal and eco-pea. 
Table 4. Selected results of a public opinion poll on energy sources, energy policy, and the state of the environment, in 2016.

\begin{tabular}{|c|c|c|}
\hline Question & Variants of Answers in the Questionnaire & $\%$ of Respondents \\
\hline \multirow{10}{*}{$\begin{array}{l}\text { The development of civilization carries, apart from } \\
\text { its positive effects, also many negative phenomena } \\
\text { and threats. Which of the following phenomena } \\
\text { would you consider to be the most dangerous? } \\
\qquad(\mathrm{N}=1000)\end{array}$} & Environment pollution & 58 \\
\hline & Desert expansion & 4 \\
\hline & Climate change & 43 \\
\hline & Depletion of non-renewable energy sources & 20 \\
\hline & Growing world population & 12 \\
\hline & Poverty & 41 \\
\hline & Civilization diseases & 51 \\
\hline & $\begin{array}{l}\text { The use of chemical compounds and genetic } \\
\text { modifications in food products }\end{array}$ & 42 \\
\hline & Other & 0 \\
\hline & Hard to say & 3 \\
\hline
\end{tabular}

Do you use the following methods of saving electricity in your household? $(\mathrm{N}=990)$

Turning off the light when leaving the room

('definitely yes' and 'rather yes' answers)

Energy-saving light bulbs ('definitely yes' and 'rather yes' answers)

Using household appliances and electronics with

low electricity consumption ('definitely yes' and 'rather yes' answers)

\footnotetext{
Do you think that your actions can contribute to the improvement of the environment in your town? $(\mathrm{N}=1000)$

Do you think that the focus should now be on development of $(\mathrm{N}=992)$
}

\begin{tabular}{cc} 
Yes & 67 \\
No & 28 \\
Hard to say & 5 \\
\hline Non-renewable energy sources & 5 \\
Renewable energy sources & 50 \\
Both of these branches of energy equally & 39 \\
Hard to say & 6 \\
\hline Definitely yes & 7 \\
Rather yes & 15 \\
Rather not & 32 \\
Definitely not & 39 \\
Hard to say & 6 \\
Not applicable (due to lack of technical conditions) & 1 \\
\hline
\end{tabular}

As part of your investment plans, in the next 2-3 years, do you consider the use of installations enabling the use of renewable energy sources in your home/farm building? $(\mathrm{N}=992)$

Source: [47].

Table 5. Energy sources used for home heating vs. respondents' financial situation.

\begin{tabular}{cccc}
\hline \multirow{2}{*}{ Respondents' Financial Situation } & \multicolumn{2}{c}{ Energy Sources Used for Home Heating } \\
\cline { 2 - 4 } & Coal & Eco-Pea & Wood \\
\hline I have to be careful with my spending but I am not lacking & $34.0 \%$ & $46.0 \%$ & $25.0 \%$ \\
\hline I don't have to limit my spending & $17.9 \%$ & $13.0 \%$ & $30.4 \%$ \\
\hline I can afford anything & $0.0 \%$ & $3.0 \%$ & $3.6 \%$ \\
\hline I can afford my basic needs & $45.5 \%$ & $36.0 \%$ & $2.0 \%$ \\
\hline I can't afford to meet my basic needs & $2.6 \%$ & $0.0 \%$ & \\
\hline
\end{tabular}




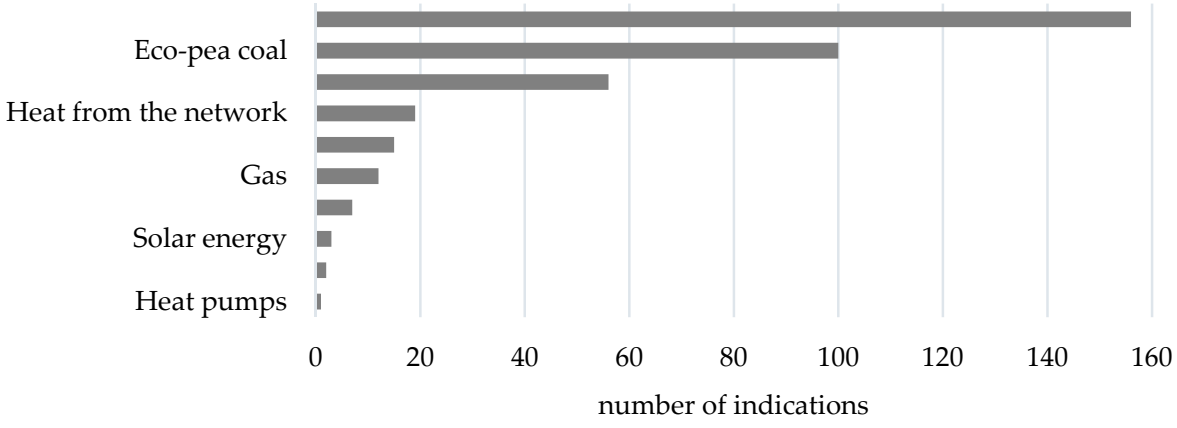

Figure 3. Structure of answers to the question: What do you heat your home with? Source: own study, $\mathrm{N}=300$.

Wood, as a source of heating, is most often used by people who, in their assessment of their material situation, declared that they can only afford their most important needs (Table 3). These are mostly people with basic vocational education. It is also worth mentioning here that wood is the most common source of heating among pensioners. Coal, on the other hand, is popular among people whose financial resources allow them to meet most of the basic needs of life. They are mainly people with secondary education, but also with basic vocational education, the vast majority of which are professionally employed. A slightly different situation was recorded in the case of eco-peas, the use of which requires additional investment costs to modernise household furnaces. Hence, the use of eco-pea coal was reported among people who declare that, although they have to watch their expenses carefully, they do not lack anything. They primarily have high school and tertiary education (Table 6) and are working professionals. Regarding the other sources of heat, which represent a decided minority compared with the conventional energy triad discussed (coal, wood, eco-pea-CWE), it is significant that they are used by people who rate their material situation as generally good or very good. For example, gas or electricity are sources used by those respondents who indicate that they do not need to limit their spending. The most innovative heat sources, which include solar energy or heat pumps, are specific to the self-employed.

Table 6. Energy sources used for home heating vs. respondents' education structure.

\begin{tabular}{cccc}
\hline \multirow{2}{*}{$\begin{array}{c}\text { Respondents' } \\
\text { Education Structure }\end{array}$} & \multicolumn{3}{c}{ Energy Sources Used for Home Heating } \\
\cline { 2 - 4 } & Coal & Eco-Pea & Wood \\
\hline primary & $17.3 \%$ & $9.0 \%$ & $19.6 \%$ \\
\hline vocational & $29.5 \%$ & $20.0 \%$ & $41.1 \%$ \\
\hline secondary & $37.2 \%$ & $38.0 \%$ & $25.0 \%$ \\
\hline tertiary & $16.0 \%$ & $33.0 \%$ & $14.3 \%$ \\
\hline
\end{tabular}

Source: own study, $\mathrm{N}=300$.

More than $80 \%$ of the respondents, and these are single-family home users, provide their own hot water supply. For this purpose, they mainly burn coal, eco-pea, or wood (Figure 4). These are energy sources used by indigenous inhabitants. More than half of the people living in the commune since birth use wood or coal, and only eco-pea coal is a raw material used to a greater extent by newcomers, including those living in the study area for less than a year (Table 7). Heat pumps or solar energy are sources specific to newcomers, living in the commune between one and five years, typically investing in new buildings. It is much easier to equip new buildings with renewable energy sources, compared with retrofitting existing buildings. European Union funds are of help here-they can co-finance ecological undertakings, reducing emissions of pollutants to the atmosphere. Very often, these types of projects are managed by local authorities, enabling local communities to obtain adequate funding and implement their undertakings [48]. According to the analysis 
performed, more than half of the respondents do not know, and, another $23.8 \%$ deny, that the commune encourages the change of heating method and investment in modern, ecological RES installations. Therefore, it is not surprising that $86 \%$ of the respondents did not use the help of local authorities when making this type of investment. Those who had the knowledge and took advantage of institutional support placed the highest importance on assistance in obtaining funding for the venture, but also on training and educational meetings.

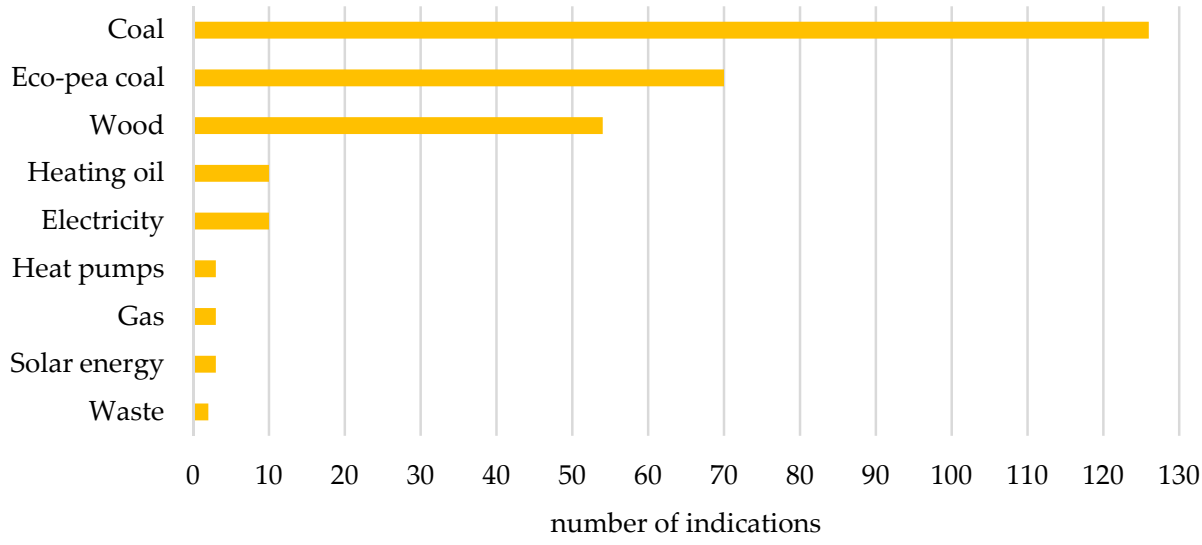

Figure 4. Structure of answers to the question: What energy source is used to heat water? Source: own study, $\mathrm{N}=300$.

Table 7. Energy sources used for water heating vs. respondents' time of residence in the commune.

\begin{tabular}{|c|c|c|c|}
\hline \multirow{2}{*}{ Respondents' Time of Residence in the Commune } & \multicolumn{3}{|c|}{ Energy Sources Used for Water Heating } \\
\hline & Coal & Eco-Pea & Wood \\
\hline less than a year & $0.0 \%$ & $5.7 \%$ & $0.0 \%$ \\
\hline $1-5$ years & $6.3 \%$ & $8.6 \%$ & $11.1 \%$ \\
\hline $6-10$ years & $14.3 \%$ & $8.6 \%$ & $9.3 \%$ \\
\hline more than 10 years but not since birth & $26.2 \%$ & $32.9 \%$ & $24.1 \%$ \\
\hline since birth & $53.1 \%$ & $44.3 \%$ & $55.5 \%$ \\
\hline
\end{tabular}

Source: own study, $\mathrm{N}=300$.

When asked about ways to reduce energy consumption in homes, the respondents primarily indicated the various manifestations of electricity conservation. Unlike heat, electricity is drawn from the grid, which requires regular payments that increase year after year. This certainly has substantial implications for energy decisions. Local initiatives in the form of caring for the rational use of electricity can be classified as a manifestation of adaptation to the changing external conditions. Among these measures, the most popular are switching off unnecessary light points and electronic equipment and using energy-saving bulbs (Figure 5). 


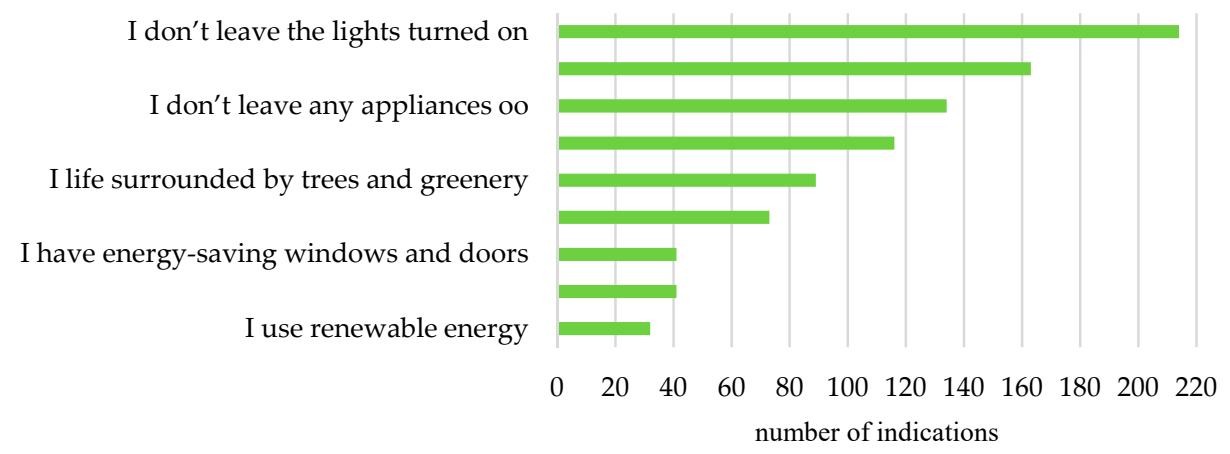

Figure 5. Structure of answers to the question: What do you do to reduce energy consumption at home? Source: own study, $\mathrm{N}=300$.

Regardless of age, all of the respondents declared that, when leaving rooms, they turn off the lights and do not leave appliances on. It is worth noting that the use of renewable energy and waste sorting are characteristic primarily of people between the ages of 35 and 44 . Saving heat, manifested by reducing heating in winter, investing in energy-efficient windows and doors, and locating the apartment in a green environment is generally popular among people over 35 years old. It is remarkable that, among seniors, the most common form of energy conservation is reducing home heating in the winter. It is worth mentioning here that $56.1 \%$ of the respondents take at least three actions to reduce energy consumption at home. In contrast, $43.9 \%$ of the respondents indicate two of such activities, at the most. A significant difference between the activity of those with primary and tertiary education becomes apparent here. The respondents with primary education choose to implement one or two ways to reduce their home energy use. In contrast, nearly $28 \%$ of those who indicate at least three home energy reduction initiatives are university-educated respondents (Table 8).

Table 8. Number of actions taken to reduce energy consumption at home vs. respondents' education.

\begin{tabular}{ccc}
\hline \multirow{2}{*}{ Respondents' Education Structure } & \multicolumn{2}{c}{ Number of Actions Taken to Reduce Energy Consumption at Home } \\
\cline { 2 - 3 } & At Most Two Actions & At Least Three Activities \\
\hline primary & $20.8 \%$ & $9.6 \%$ \\
\hline vocational & $24.6 \%$ & $23.5 \%$ \\
\hline secondary & $40.8 \%$ & $39.2 \%$ \\
\hline tertiary & $13.8 \%$ & $27.7 \%$ \\
\hline
\end{tabular}

Source: own study, $\mathrm{N}=300$.

Nevertheless, regardless of the declared way of saving energy, when evaluating their material situation, at least $40 \%$, and in some cases, even $60 \%$ of the respondents, say that they have to watch their expenses carefully, even though they do not lack anything. People with much more modest financial resources focus their actions on saving both electricity and heat. On the other hand, those who assess their material situation as good or very good, in addition to saving measures, also undertake investments aimed at increasing the energy efficiency of their households, e.g., through the purchase of RES installations.

\subsubsection{Local Communities' Energy Awareness and Attitude}

In addition to financial issues, the way households operate in terms of rural resilience is also determined by the energy awareness of local communities, which is a leading element of environmental awareness [49]. What, then, are the foundations for creating this awareness? The key to answering this question is the local context, as it is the immediate environment that shapes the attitudes and energy behaviour of the population. Analysing the structure of answers to the question about the sources of information on how to save 
energy, one can see a significant correlation of age and the natural social environment of a given age group as the primary source of shaping energy awareness and thus ecological awareness (Table 9). This is why, for instance, the youngest respondents-under the age of 24-draw on what they hear at school. Professionally active people, mostly of mobile working age, acquire relevant knowledge from work, but also from the Internet. Television, books, and friends and family are also important sources of knowledge for adults. Friends and family are also important sources of information for seniors. This is related to the traditional social resources identified in rural areas, which are based on family and neighbourly ties and trust in those closest to them [50]. It is worth noting that only those who want to invest in the energy efficiency of their households are interested in having professional knowledge provided to them through courses and trainings.

Table 9. Sources of information on how to save energy vs. age of respondents.

\begin{tabular}{cccccccc}
\hline \multirow{2}{*}{ Age of Respondents } & \multicolumn{7}{c}{ Sources of Information on How to Save Energy } \\
\cline { 2 - 8 } & School & Work & Internet & TV & Friends, Family & Books & Courses, Training \\
\hline $18-24$ & $80.0 \%$ & $5.1 \%$ & $18.6 \%$ & $9.7 \%$ & $8.3 \%$ & $12.9 \%$ & $0.0 \%$ \\
\hline $25-34$ & $20.0 \%$ & $30.8 \%$ & $26.7 \%$ & $19.9 \%$ & $11.0 \%$ & $9.7 \%$ & $33.3 \%$ \\
\hline $35-44$ & $0.0 \%$ & $35.9 \%$ & $33.7 \%$ & $30.1 \%$ & $24.8 \%$ & $22.6 \%$ & $33.3 \%$ \\
\hline $45-64$ & $0.0 \%$ & $25.6 \%$ & $18.6 \%$ & $30.7 \%$ & $33.0 \%$ & $35.5 \%$ & $33.3 \%$ \\
\hline 65 and over & $0.0 \%$ & $2.6 \%$ & $2.3 \%$ & $9.7 \%$ & $22.9 \%$ & $19.4 \%$ & $0.0 \%$ \\
\hline
\end{tabular}

Regardless of the education level, the most recognised RES are wind, solar, and hydro power. Considering the number of known RES indicated, 70\% of those who confirmed knowledge of at least two RES are respondents with secondary and higher education. The immediate environment is what influences the extent and state of knowledge, and, more broadly, awareness. This is proven by the fact that the least commonly known RES, i.e., biomass and biogas, are the most popular among those working on their own farm, including those with primary education. This is because their farming operations are the primary source of raw materials for both biomass and biogas production.

Nearly $43 \%$ of the respondents said that they would like to use energy from RES in the future. Nearly $70 \%$ of them have secondary or tertiary education. Solar energy is the undisputed leader here, followed by wind and hydropower (Figure 6). Moreover, more than $35 \%$ of the respondents, primarily those with secondary and higher education (70.5\%), believe that homes equipped with RES installations stand out from the others. In addition to the green argument, the other most important ones are fashion and aesthetic appeals of RES homes, lower operating costs, and increased value of the buildings. This is declared primarily by those who currently use wood, coal, or eco-pea coal as their primary heat source (Table 10).

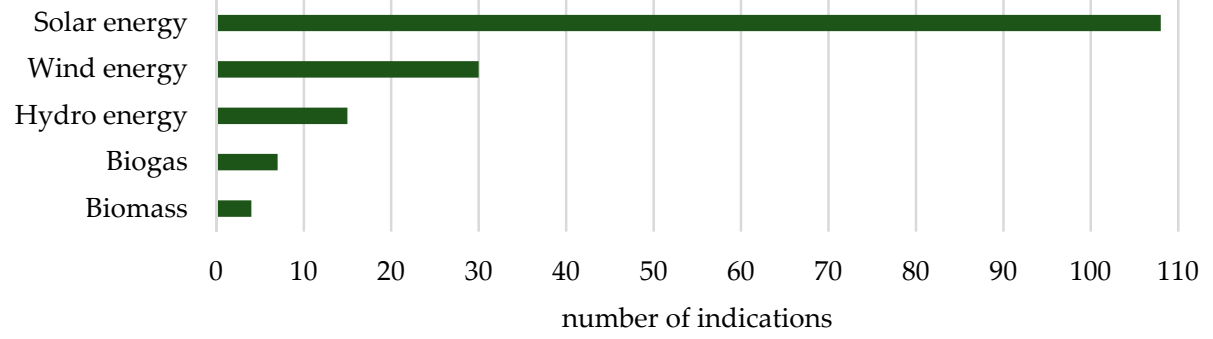

Figure 6. Structure of answers to the question: Which RES would you like to use in the future? Source: own study, $\mathrm{N}=300$. 
Table 10. How RES-equipped homes stand out vs. the energy sources used to heat the home.

\begin{tabular}{|c|c|c|c|c|c|}
\hline \multirow[b]{2}{*}{$\begin{array}{c}\text { Energy Sources } \\
\text { Used to Heat the } \\
\text { Home }\end{array}$} & \multicolumn{5}{|c|}{ How RES-Equipped Homes Stand Out? } \\
\hline & $\begin{array}{c}\text { They Are More } \\
\text { Ecological }\end{array}$ & $\begin{array}{l}\text { They Are } \\
\text { Fashionable }\end{array}$ & $\begin{array}{c}\text { They Are Cheaper } \\
\text { to Operate }\end{array}$ & $\begin{array}{l}\text { They Meet the } \\
\text { Highest } \\
\text { Standards of } \\
\text { Construction }\end{array}$ & $\begin{array}{c}\text { You Can Sell } \\
\text { Them at a Higher } \\
\text { Price }\end{array}$ \\
\hline coal & $43.9 \%$ & $50.8 \%$ & $53.3 \%$ & $45.5 \%$ & $50.0 \%$ \\
\hline eco-pea & $23.5 \%$ & $20.6 \%$ & $26.7 \%$ & $33.3 \%$ & $23.1 \%$ \\
\hline wood & $20.4 \%$ & $19.0 \%$ & $15.6 \%$ & $18.2 \%$ & $23.1 \%$ \\
\hline gas & $5.1 \%$ & $6.4 \%$ & $0.0 \%$ & $0.0 \%$ & $1.9 \%$ \\
\hline electricity & $5.1 \%$ & $1.6 \%$ & $4.4 \%$ & $3.0 \%$ & $1.9 \%$ \\
\hline solar energy & $1.0 \%$ & $0.0 \%$ & $0.0 \%$ & $0.0 \%$ & $0.0 \%$ \\
\hline heat pumps & $1.0 \%$ & $1.6 \%$ & $0.0 \%$ & $0.0 \%$ & $0.0 \%$ \\
\hline
\end{tabular}

Source: own study, $\mathrm{N}=300$.

\section{Discussion}

\subsection{Energy Awareness, Attitudes and Behaviour of the Locals-Hot and Blind Spots}

An analysis of the three key dimensions of local community energy literacy (awareness, attitude, and behaviour) has proven that the energy behaviours of the local community members point to a varied degree of energy literacy based on their knowledge of key energy transition issues. Although local communities are currently primarily the consumers of energy from traditional energy carriers (CWE) used for both home heating and water heating, they have a basic understanding of RES. Moreover, they notice non-environmentally positive aspects of equipping households with RES installations (e.g., lower operating costs and higher property value), and, most importantly, they express interest in using RES in their households. As in other countries [51,52], the main predictor of energy behaviour in Poland can be seen in the available financial resources. Hard coal and wood are the primary energy sources for the heating of homes of those with rather low income, allowing them to meet their basic needs. In turn, unconventional energy sources are used primarily in the households who assess their material situation as good or very good, often newcomers, investing in new buildings. The dependence of the various methods of rational energy use on the age and education of the inhabitants is visible. The reduction of heating in winter is characteristic mainly of seniors, i.e., people over 65 years of age. The use of renewable energy, which is, in fact, used by the inhabitants of the commune to a very small extent, is the domain of people between 35 and 44 years of age. People with higher education are much more active in the area of energy efficiency measures, usually using several methods to reduce energy consumption at home. In Poland, the average income of the population increases with a growing level of their education $[53,54]$, which may explain the relatively greater activities aimed at reducing energy consumption, by people with higher education.

We should also remember that it is not only a question of the rational use of energy, which is partly a necessity due to the rising energy prices and the large share of energy expenditure in household budgets. It is also a matter of reformulating the dominant model of economy, which is based on conventional energy sources, and which has been the established modus operandi for decades in Poland, both in the industry and residential sectors $[55,56]$. In this regard, it is important to recognise this first, though perhaps not yet fully determined, step toward generating a locally sustainable resilience, both technical and social, which is, as mentioned earlier, one of the key elements of rural resilience. This is crucial in rural areas, as rural people, including Polish farmers, have the lowest adaptive capacity in Europe [57].

\subsection{The Core of Increasing the Locals' Energy Literacy}

Conscious, structured activities related to building rural resilience require a greater focus on the local context of residents' energy awareness, i.e., using their immediate environment, which has the greatest impact on shaping their energy attitudes and behaviour $[39,40]$. 
Therefore, it would be advisable to use such channels for the dissemination of knowledge on how to use energy rationally, the impact of household energy decisions on climate change, as well as the basic knowledge to carry out the financial calculations underpinning the investment decisions for energy consumers; by virtue of 'proximity', these would be the most acceptable to local residents and could have the greatest impact on their future energy choices, leading the local community toward strengthening rural power-system resilience. Global research provides compelling evidence that energy literacy enables more efficient consumption and more environmentally friendly choices [4]. Energy literacy and, in particular, investment (financial) literacy have a positive role in reducing household electricity consumption [58] and deciding on the selection of cost-efficient appliances [59]. People who are aware of environmental problems and who have positive environmental knowledge show responsible environmental and energy behaviours [60-64].

The issue of promoting energy literacy among the members of local communities living in rural areas in Poland, particularly the dissemination of knowledge about various aspects of energy transition, is important in the context of not only building rural powersystem resilience, but also reducing the risk of household energy poverty, which is very high in rural areas [65]. An insufficient level of energy literacy is obviously not the only factor that determines energy choices, and not the only hurdle to renewable energy implementation. The problem is much more complex [52,66,67]. An effective solution should address all unfavorable situations and their causes in the field of energy affecting the choices of households in Poland, especially in rural areas, which requires an integrated package of instruments (Figure 7). In addition to educational provisions, this solution should also include public support: institutional and financial assistance for households and the promotion of appropriate legislation.

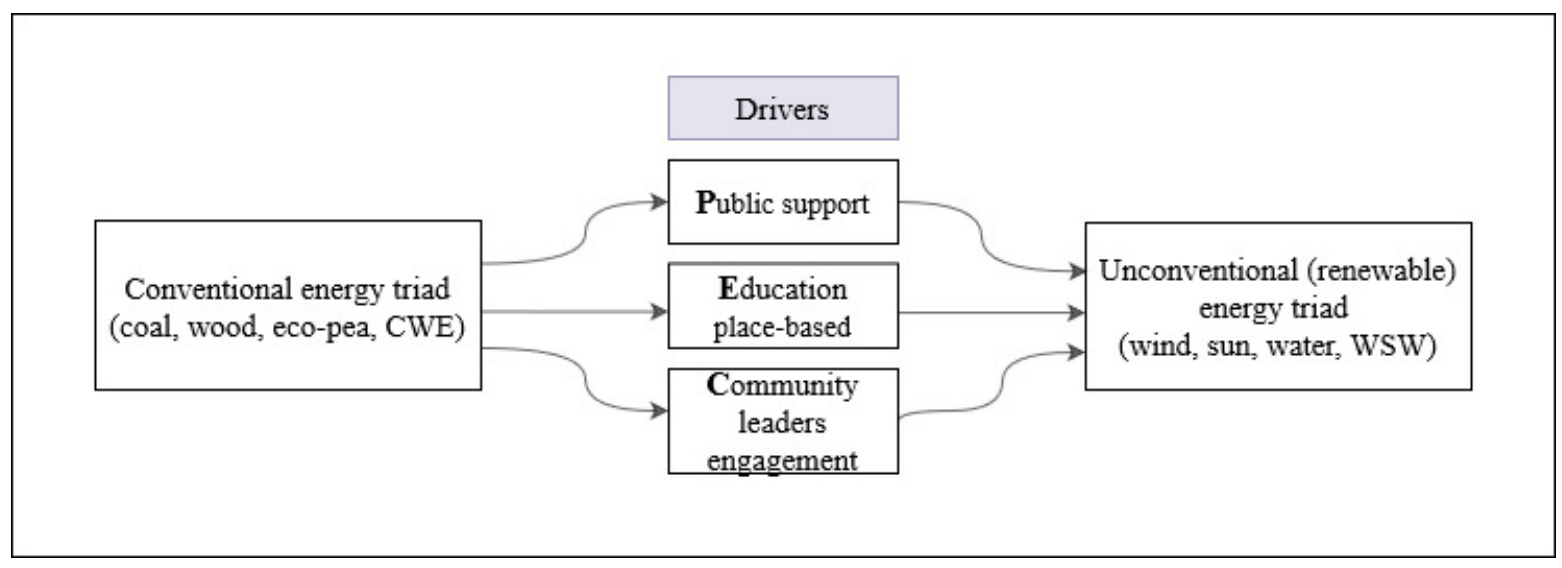

Figure 7. Toward a rural resilience. Source: own study.

The issue of promoting energy literacy among the members of local communities living in rural areas in Poland, and the dissemination of knowledge about various aspects of energy transition are important not only for building a rural power-system resilience, but also for reducing the risk of household energy poverty, which is very high in those areas [65]. This is of critical importance because, as indicated earlier, both rural powersystem resilience and energy poverty reduction are the prerequisites for a just energy transition. Regarding the problem of energy poverty, it should be emphasised that among its driving forces (in addition to technical and economic ones) are the households' needs and/or practices of energy use, which often lead to significant energy losses (due to improper use of various appliances) and, consequently, to an increase in energy expenses, beyond the level that a household can afford ([68], p. 252). A factor that shapes and corrects energy attitudes and behaviour is knowledge about the efficient use of heating and electrical appliances and about opportunities to invest in solutions with higher energy efficiency (e.g., energy efficient light bulbs, thermal insulation of buildings, and so on) ([69], pp. 5-6). 
Thus, it seems that in the case of local communities, especially where energy poverty is significant, advice on energy use and how to implement investments in improving the energy efficiency of housing, provided by public services and local nongovernmental organizations (NGOs), can be of great importance ([69], pp. 5-6). Among the latter, Local Action Groups (LAGs) may be the key actors. Their functioning is a manifestation of multilevel governance over the development of territorial units in the EU, and, more specifically, of the implementation of the regional development initiative called Community-Led Local Development [70]. By combining the varying resources and skills of partners from different sectors (public, private, voluntary, and community) rooted in the local socio-economic environment, LAGs, taking account of the local social, environmental, and economic needs, design and implement integrated development strategies in which they offer solutions tailored to local circumstances and provide resources which add up to more than the sum of the parts [71]. As such, LAGs appear to have the attributes of an ideal educator on local energy problems, and thus are creators of rural resilience. Undoubtedly, the foundation for a successful rural energy transition is the trans-sectoral cooperation of local actors centred around the needs and expectations of local communities and the creation of a strong sense of belonging and proactive attitudes [72,73]. It is worth emphasising here that activities such as development of NGOs, activation of residents, and building social interaction and mutual trust are essential components for implementing the concept of rural resilience $[32,51,74]$; these also have the potential to have a role in further increasing the social capital in rural areas.

\section{Conclusions}

This study demonstrates the concerns and practices of a local community that accurately reflects the energy profile of the Polish society living in rural peripheral areas. This consumer profile comprises of energy that is derived mainly from conventional sources, including primarily hard coal. However, it is most often used by people with relatively low income, the level of which allows them to meet their most important needs of life. Unconventional energy sources are used mainly in households, often newcomers, who assess their material situation as good or very good, and who invest in new buildings.

At the same time, there are some indications that the ecological awareness of rural residents is being formed. On the one hand, the needs for a rational management of energy, including electricity and heat, come to the fore. On the other hand, we can observe various types of investments improving the energy efficiency of residential buildings and enabling energy generation based on RES. These have the potential to become vectors for a just and sustainable rural energy transition, but only if backed by educational reinforcement and long-term institutional support centered on local context and social capital. Promoting legislation that is favourable to the establishment and deployment of energy communities, as the European Commission is currently implementing, is a proper step in this direction. The analysis of the possibilities of implementing these instruments in Poland and the assessment of their effectiveness constitute a field for further research.

Author Contributions: Conceptualization, S.M., J.C.-M., and M.K.-B.; methodology, S.M., J.C.-M., and A.L.; software, J.C.-M. and A.L.; validation, S.M., J.C.-M., M.K.-B., and A.L.; formal analysis, J.C.-M. and A.L.; investigation, J.C.-M., and M.K.-B.; resources, J.C.-M. and M.K.-B.; data curation, S.M. and J.C.-M.; writing—original draft preparation, J.C.-M., M.K.-B., and A.L.; writing—review and editing, S.M., J.C.-M., M.K.-B., and A.L.; visualization, J.C.-M. and A.L.; supervision, S.M., J.C.-M., M.K.-B., and A.L.; project administration, S.M.; funding acquisition, J.C.-M. and M.K.-B. All authors have read and agreed to the published version of the manuscript.

Funding: This research was funded by The National Science Centre, Poland, Project no. 2016/21/D/ HS4/00714: Biogas enterprises from the perspective of the embeddedness concept.

Institutional Review Board Statement: Not applicable.

Informed Consent Statement: Informed consent was obtained from all subjects involved in the study. 
Data Availability Statement: Original data is available on the request in the personal archives of the authors.

Acknowledgments: We would like to express our gratitude to Nicolaus Copernicus University Center of Excellence Interacting Minds, Societies, Environment (IMSErt) and the respondents of our survey for supporting the data necessary for this research.

Conflicts of Interest: The authors declare no conflict of interest.

\section{References}

1. Beck, U. Społeczeństwo Ryzyka. W drodze do Innej Nowoczesności; Wydawnictwo Scholar: Warszawa, Poland, 2004.

2. Strzelecka, E. Concept of Resilience and Development of Small Towns and Rural Area. Barom. Reg. 2018, 16, 121-130.

3. Henderson, F.; Steiner, A.; Farmer, J.; Whittam, G. Challenges of community engagement in a rural area: The impact of flood protection and policy. J. Rural Stud. 2020, 73, 225-233. [CrossRef]

4. Martins, A.; Madaleno, M.; Dias, M.F. Energy literacy assessment among Portuguese university members: Knowledge, attitude, and behavior. Energy Rep. 2020, 6, 243-249. [CrossRef]

5. Coles, T.; Dinan, C.; Warren, N. Energy practices among small- and medium-sized tourism enterprises: A case of misdirected effort? J. Clean. Prod. 2014, 111 Pt B, 399-408. [CrossRef]

6. Sovacool, B.K. Evaluating energy security in the Asia pacific: Towards a more comprehensive approach. Energy Policy 2011, 39, 7472-7479. [CrossRef]

7. Van den Broek, K. Household energy literacy: A critical review and a conceptual typology. Energy Res. Soc. Sci. 2019, 57. [CrossRef]

8. Robison, R.; Skjølsvold, T.M.; Lehne, J.; Judson, E.; Pechancová, V.; Foulds, C.; Bilous, L.; Büscher, C.; Carrus, G.; Darby, S.; et al. 100 Social Sciences and Humanities Priority Research Questions for Smart Consumption in Horizon Europe; Energy-SHIFTS: Cambridge, UK, 2020; Available online: https:/ / energy-shifts.eu/wp-content/uploads/2020/12/D2.3_WG2_smart-consumption.pdf (accessed on 11 February 2021).

9. Brounen, D.; Kok, N.; Quigley, J.M. Energy literacy, awareness, and conservation behavior of residential households. Energy Econ. 2013, 38. [CrossRef]

10. Sovacool, B.K.; Blyth, P.L. Energy and environmental attitudes in the green state of Denmark: Implications for energy democracy, low carbon transitions, and energy literacy. Environ. Sci. Policy 2015, 54. [CrossRef]

11. Carlsson-Kanyama, A.; Lindén, A.-L. Energy efficiency in residences-Challenges for women and men in the North. Energy Policy 2007, 35, 2163-2172. [CrossRef]

12. DeWaters, J.E.; Powers, S.E. Energy literacy of secondary students in New York State (USA): A measure of knowledge, affect, and behavior. Energy Policy 2011, 39, 699-710. [CrossRef]

13. DeWaters, J.; Qaqish, B.; Graham, M.; Powers, S. Designing an energy literacy questionnaire for middle and high school youth. J. Environ. Educ. 2013, 44, 56-78. [CrossRef]

14. Lee, L.-S.; Lee, Y.-F.; Wu, M.-J.; Pan, Y.-J. A study of energy literacy among nursing students to examine implications on energy conservation efforts in Taiwan. Energy Policy 2019, 135. [CrossRef]

15. Kalmi, P.; Trotta, G.; Kazukauskas, A. The role of energy literacy as a component of financial literacy: Survey-based evidence from Finland. In Proceedings of the IAEE Conference, Vienna, Austria, 3-6 September 2017.

16. Blasch, J.; Boogen, N.; Daminato, C.; Filippini, M. Empower the Consumer! Energy-Related Financial Literacy and Its Socioeconomic Determinants; CER-ETH-Center of Economic Research: Zurich, Switzerland, 2018. [CrossRef]

17. Martins, A.; Madaleno, M.; Dias, M.F. Energy literacy: What is out there to know? Energy Rep. 2020, 6, 454-459. [CrossRef]

18. Remund, D.L. Financial literacy explicated: The case for a clearer definition in an increasingly complex economy. J. Consum. Aff. 2010, 44, 276-295. [CrossRef]

19. Vainio, A.; Pulkka, A.; Paloniemi, R.; Varho, V.; Tapio, P. Citizens' sustainable, future-oriented energy behaviours in energy transition. J. Clean. Prod. 2020, 245. [CrossRef]

20. Folke, C. Resilience: The emergence of a perspective for social-ecological systems analyses. Glob. Environ. Chang. 2006, 16, 253-267. [CrossRef]

21. Perez, C.; Jones, E.M.; Kristjanson, P.; Cramer, L.; Thornton, P.K.; Förch, W.; Barahona, C. How resilient are farming households and communities to a changing climate in Africa? A gender-based perspective. Glob. Environ. Chang. 2015, 34, 96-107. [CrossRef]

22. Heijman, W.; Hagelaar, G.; van der Heide, M. Rural resilience as a new development concept. 100th Seminar, 21-23 June 2007, Novi Sad, Serbia and Montenegro from European Association of Agricultural Economists. Available online: https: / /EconPapers.repec.org/RePEc:ags:eaa100:162359 (accessed on 11 February 2021).

23. Dacko, A.; Dacko, M. Studies on the Development of Rural Areas-From the Growth Paradigm to Resilience. Wieś $i$ Rolnictwo 2018, 2, 49-64. [CrossRef]

24. Adger, W.N.; Hughes, T.P.; Folke, C.; Carpenter, R.; Rockström, J. Social-Ecological Resilience to Coastal Disasters. Science 2005, 309, 1036-1039. [CrossRef] [PubMed]

25. Miller, F.; Osbahr, H.; Boyd, E.; Thomalla, F.; Bharwani, S.; Ziervogel, G.; Walker, B.; Birkmann, J.; van der Leeuw, S.; Rockstrom, J.; et al. Resilience and vulnerability: Complementary or conflicting concepts? Ecol. Soc. 2010, 15, 11. [CrossRef] 
26. Umetsu, C. Vulnerability and Resilience of Social-Ecological Systems; Inter-University Research Institute Corporation, National Institutes for the Humanities Research Institute for Humanity and Nature: Kyoto, Japan, 2010.

27. Schouten, M.; van der Heide, M.; Heijman, W.; Opdam, P. A resilience-based policy evaluation framework: Application to European rural development policies. Ecol. Econom. 2012, 81, 165-175. [CrossRef]

28. Mazur, C.; Hoegerle, Y.; Brucoli, M.; van Dam, K.; Guo, M.; Markides, C.N.; Shah, N. A holistic resilience framework development for rural power systems in emerging economies. Appl. Energy 2019, 235, 219-232. [CrossRef]

29. Bouzarovski, S.; Thomson, H. Transforming Energy Poverty Policies in The European Union: Second Annual Report of The European Union Energy Poverty Observatory. 2019. Available online: https:/ /www.energypoverty.eu/sites/default/files/ downloads/observatory-documents/20-01/epov_pan-eu_report_2019_final.pdf (accessed on 10 January 2021).

30. Arsenopoulos, A.; Marinakis, V.; Koasidis, K.; Stavrakaki, A.; Psarras, J. Assessing Resilience to Energy Poverty in Europe through a Multi-Criteria Analysis Framework. Sustainability 2020, 12, 4899. [CrossRef]

31. Kythreotis, A.P.; Bristow, G.I. The 'resilience trap': Exploring the practical utility of resilience for climate change adaptation in UK city-regions. Reg. Stud. 2017, 51, 1530-1541. [CrossRef]

32. Skerrat, S.; Steiner, A. Working with communities-of-place: Complexities of empowerment. Local Econ. 2013, 28, 320-338. [CrossRef]

33. Olave, M.S.; Vargas-Payera, S. Environmental impact assessment and public participation of geothermal energy projects: The cases of Chile, Costa Rica, Colombia, and Mexico. In The Regulation and Policy of Latin American Energy Transitions; Guimarães, L.N., Ed.; Elsevier Science: Amsterdam, The Netherlands, 2020.

34. Zużycie Energii w Gospodarstwach Domowych w 2018 r. Główny Urząd Statystyczny, 2019. Available online: https: //stat.gov.pl/download/gfx/portalinformacyjny/pl/defaultaktualnosci/5485/2/4/1/zuzycie_energii_w_gospodarstwach_ domowych_w_2018.pdf (accessed on 11 February 2021).

35. Local Data Bank of Statistics Poland, LDB SP. Available online: https:/ / bdl.stat.gov.pl/ (accessed on 5 January 2021).

36. Gorard, S. The role of secondary data in combining methodological approaches. Educ. Rev. 2002, 54, 231-237. [CrossRef]

37. Owczarek, D.; Miazga, A. Ubóstwo Energetyczne w Polsce—Definicja i Charakterystyka Społeczna Grupy; Instytut na Rzecz Ekorozwoju: Warszawa, Poland, 2015. Available online: https://www.pine.org.pl/wp-content/uploads/pdf/ubostwo_energet_polska.pdf (accessed on 5 January 2021).

38. Strategia Rozwoju Województwa Kujawsko-Pomorskiego do 2030 Roku—Strategia Przyspieszenia 2030+, Załącznik do Uchwały nr XXVIII/399/20 Sejmiku Województwa Kujawsko-Pomorskiego Z dnia 21 Grudnia 2020 r. Available online: https: / / kujawskopomorskie.pl/pliki/2020/planowanie/20201229_strategia/Strategia_Przyspieszenia_2030plus.pdf (accessed on 20 January 2021).

39. Chodkowska-Miszczuk, J.; Martinat, S.; Cowell, R. Community tensions, participation, and local development: Factors affecting the spatial embeddedness of anaerobic digestion in Poland and the Czech Republic. Energy Res. Soc. Sci. 2019, 55, 134-145. [CrossRef]

40. Lewandowska, A.; Chodkowska-Miszczuk, J.; Rogatka, K.; Starczewski, T. Smart Energy in a Smart City: Utopia or Reality? Evidence from Poland. Energies 2020, 13, 5795. [CrossRef]

41. Babbie, E. Badania Społeczne w Praktyce; Wydawnictwo Naukowe PWN: Warszawa, Poland, 2004.

42. Sato, J. Comparison between multiple-choice and analytic hierarchy process: Measuring human perception. Intl. Trans. Opt. Res. 2004, 11, 77-86. [CrossRef]

43. Francis, J.J.; Johnston, M.; Robertson, C.; Glidewell, L.; Entwistle, V.; Eccles, M.P.; Grimshaw, J.M. What is an adequate sample size? Operationalising data saturation for theory-based interview studies. Psychol. Health 2010, 25, 1229-1245. [CrossRef] [PubMed]

44. Schwarz, N.; Hippler, H.J. What Response Scales may Tell your Respondents: Informative Functions of Response Alternatives. In Social Information Processing and Survey Methodology. Recent Research in Psychology; Hippler, H.J., Schwarz, N., Sudman, S., Eds.; Springer: New York, NY, USA, 1987. [CrossRef]

45. Eurostat. Available online: https:/ / ec.europa.eu/eurostat (accessed on 29 January 2021).

46. Lewandowski, P.; Kiełczewska, A.; Ziółkowska, K. Zjawisko Ubóstwa Energetycznego w Polsce, w Tym ze Szczególnym Uwzględnieniem Zamieszkujących w Domach Jednorodzinnych. IBS Research Report 02/2018, Kwiecień 2018. Available online: https:/ /ibs.org.pl/app/uploads/2018/06/IBS_Research_Report_02_2018_pl.pdf (accessed on 11 February 2021).

47. Centrum Badania Opinii Społecznej. Polacy o źródłach Energii, Polityce Energetycznej i Stanie środowiska. Gwiazda, M., Ruszkowski, P., Eds.; Opinie i diagnozy nr 34. 2016. Available online: https://www.cbos.pl/PL/publikacje/diagnozy/034.pdf (accessed on 11 February 2021).

48. Chodkowska-Miszczuk, J.; Biegańska, J.; Środa-Murawska, S.; Grzelak-Kostulska, E.; Rogatka, K. European Union funds in the development of renewable energy sources in Poland in the context of the cohesion policy. Energy Environ. 2016, $27,713-725$. [CrossRef]

49. Dylag, A. Świadomość ekologiczna i energetyczna młodzieży dużego i małego miasta w województwie łódzkim. In Bezpieczeństwo Energetyczne. Rynki Surowców i Energii-Teraźniejszość i Przyszłość. Geopolityka—Polska—Świat; Kwiatkiewicz, P., Ed.; Fundacja na Rzecz Czystej Energii: Bydgoszcz, Poland, 2014; pp. 401-420.

50. Frazier, B.J.; Niehm, L.S. Exploring business information networks of small retailers in rural communities. J. Dev. Entrep. 2004, 9, 23-42. 
51. Rapaport, C.; Hornik-Lurieb, T.; Cohen, O.; Lahade, M.; Leykin, D.; Aharonson-Daniel, L. The relationship between community type and community resilience. Int. J. Disast. Risk Reduct. 2018, 31, 470-477. [CrossRef]

52. Quinlan, M. Five challenges to humanity: Learning from pattern/repeat failures in past disasters? Econ. Lab. Relat. Rev. 2020, 31, 444-466. [CrossRef]

53. Ogólnopolskie Badanie Wynagrodzeń w 2019 roku. 2020. Available online: https://wynagrodzenia.pl/artykul/jak-poziomwyksztalcenia-wplywa-na-wynagrodzenie (accessed on 11 February 2021).

54. Kapitał Ludzki w Polsce w Latach 2014-2018. Główny Urząd Statystyczny, 2020. Available online: https://stat.gov.pl/download/ gfx/portalinformacyjny/pl/defaultaktualnosci/5501/8/7/1/kapital_ludzki_w_polsce_w_latach_2014-2018.pdf (accessed on 11 February 2021).

55. Rosicki, E. Kultury Energetyczne Unii Europejskiej; Wydawnictwo Naukowe Wydziału Nauk Politycznych i Dziennikarstwa: Poznań, Poland, 2018.

56. Żuk, P.; Żuk, P.; Pluciński, P. Coal basin in Upper Silesia and energy transition in Poland in the context of pandemic: The socio-political diversity of preferences in energy and environmental policy. Res. Policy 2021, 71, 101987. [CrossRef]

57. Vanschoenwinkel, J.; Mendelsohn, R.; Van Passel, S. Do Western and Eastern Europe have the same agricultural climate response? Taking adaptive capacity into account. Glob. Environ. Chang. 2016, 41, 74-87. [CrossRef]

58. Blasch, J.; Boogen, N.; Filippini, M.; Kumar, N. Explaining electricity demand and the role of energy and investment literacy on end-use efficiency of Swiss households. Energy Econ. 2017, 68, 89-102. [CrossRef]

59. Blasch, J.; Filippini, M.; Kumar, N. Boundedly rational consumers, energy and investment literacy, and the display of information on household appliances. Resour. Energy Econ. 2019, 56, 39-58. [CrossRef]

60. Carmi, N.; Arnon, S.; Orion, N. Transforming environmental knowledge into behavior: The mediating role of environmental emotions. J. Environ. Educ. 2015, 46, 183-201. [CrossRef]

61. Echegaray, F.; Hansstein, F.V. Assessing the intention-behavior gap in electronic waste recycling: The case of Brazil. J. Clean. Prod. 2017, 142, 180-190. [CrossRef]

62. Malkki, H.; Alanne, K. An overview of life cycle assessment (LCA) and research based teaching in renewable and sustainable energy education. Renew. Sustain. Energy Rev. 2017, 69, 218-231. [CrossRef]

63. Pothitou, M.; Hanna, R.F.; Chalvatzis, K.J. Environmental knowledge, pro-environmental behaviour and energy savings in households: An empirical study. Appl. Energy 2016, 184, 1217-1229. [CrossRef]

64. Pothitou, M.; Varga, L.; Kolios, A.J.; Gu, S. Linking energy behaviour, attitude and habits with environmental predisposition and knowledge. Int. J. Sustain. Energy 2017, 36, 398-414. [CrossRef]

65. Sokołowski, J.; Lewandowski, P.; Kiełczewska, A.; Bouzarovski, S. A multidimensional index to measure energy poverty: The Polish case. Energy Sources Part B: Econ. Plan. Policy 2020, 15, 92-112. [CrossRef]

66. Hess, D.J.; Maki, A. Climate change belief, sustainability education, and political values: Assessing the need for higher-education curriculum reform. J. Clean. Prod. 2019, 228, 1157-1166. [CrossRef]

67. Brauers, H.; Oei, P.-Y. The political economy of coal in Poland: Drivers and barriers for a shift away from fossil fuels. Energy Policy 2020, 144, 111621. [CrossRef]

68. Simcock, N.; Thomson, H.; Petrova, S.; Bouzarovski, S. (Eds.) Conclusions. In Energy Poverty and Vulnerability. A Global Perspective; Routledge: London, UK; New York, NY, USA, 2018.

69. Boguszewski, R.; Herudziński, T. Ubóstwo Energetyczne w Polsce. Pracownia Badań Społecznych SGGW. 2018. Available online: https:/ / www.cire.pl/pliki/2/2018/ubostwo_energetyczne_w_polsce_raport_03_09_2018.pdf (accessed on 11 February 2021).

70. Kola-Bezka, M. Community-led local development in urban and other areas: Lessons from Kujawsko-Pomorskie voivodship. Econ. Law 2020, 19, 505-521. [CrossRef]

71. Kola-Bezka, M. Are LAGs contributing to solving social exclusion problems? The case of Kujawsko-Pomorskie Voivodship. Bull. Geography. Socio-econ. Ser. 2020, 48, 35-45. [CrossRef]

72. McManus, P.; Walmsley, J.; Argent, N.; Baum, S.; Bourke, L.; Martin, J.; Pritchard, B.; Sorensen, T. Rural Community and Rural Resilience: What is important to farmers in keeping their country towns alive? J. Rural Stud. 2012, 21, 20-29. [CrossRef]

73. Gwosdz, K.; Domański, B.; Bilska-Wodecka, E. Localised capabilities as an intermediating factor in the transition from an old to a new development path: The case of post-socialist industrial towns. Morav. Geogr. Rep. 2020, 28, 124-135. [CrossRef]

74. Van der Horst, D. Landscapes of lost energy: Counterfactual geographical imaginary for a more sustainable society. Morav. Geogr. Rep. 2014, 22, 66-72. [CrossRef] 